\title{
IBN MISKAWAIH Filsafat al-Nafs dan al-Akhlāq
}

\author{
Safii \\ Institut Agama Islam Negeri (IAIN) Walisongo Semarang \\ e-mail:imamsa_fii@yahoo.com
}

\begin{abstract}
Ibn Miskawayh known not only in philosophy but also in other fields of scientific disciplines, such as history and Arabic literature. Even through one of his master piece, entitled Tahżīb al-Akhlāq wa Tatkhïr al-A'rāq name is becoming increasingly popular in many parts of the world. On this occasion the author deems it necessary to show the figure of Ibn Miskawayh by stressing his thoughts on the study of the study of nafs philosophy and morals. According to Ibn Miskawayh explained that between the soul and the sense that one is.That is the soul and intellectin his view can not be distinguished. Even sense to him it is one of the power of the forces that existin the soul and is a manifestation of the existence of the soul it self. Thus it can be said that there a son bagi inya is one proof for the existence of the soul.
\end{abstract}

Abstrak: Ibn Miskawaih dikenal tidak hanya dalam bidang filsafatnya melainkan juga dalam bidang disiplin keilmuan lainnya, seperti sejarah dan sastra Arab. Bahkan melalui salah satu master piece-nya yang berjudul Tahżìb al-Akhlāq wa Tatkhīr al-A'rāq namanya menjadi semakin populer di berbagai belahan dunia. Dalam kesempatan ini penulis memandang perlu untuk menampilkan sosok Ibn Miskawaih tersebut dengan stressing kajian pada telaah pemikirannya tentang filsafat al-nafs dan al-akhlak-nya. Menurut Ibn Miskawaih menerangkan bahwa antara jiwa dan akal itu satu 
SAFII:Ibn Miskawaih: Filsafat al-Nafs dan al-Akhlāq

dapatlah dikatakan bahwa akal baginya merupakan salah satu bukti bagi adanya jiwa.

Keywords: akhlak, filsafat, Yunani, al-nafs, al-akhlāq

\section{A. Pendahuluan}

Seiring dengan ekspansi yang dimotori oleh Iskandar Agung (Alexander The Great) ke daratan Timur Tengah pada permulaan abad keempat sebelum Masehi, bersamanya ikut pula ambil bagian beberapa ahli pikir Yunani untuk menyebarkan pemikiran-pemikirannya. Dengan penaklukan ini pemikiran-pemikiran filsafat berkembang di daerah tersebut, sehingga dikenallah apa yang di dalam sejarah disebut dengan kebudayaan Hellenisme. ${ }^{1}$

Tidak lama menjelang Islam lahir, agama Masehi telah memiliki kekuatan politik yang begitu besar di bawah kaisar Yustinius di Konstantinopel. Dengan kekuasaannya agama ini kemudian melarang kepada publik agar tidak mempelajari filsafat, karena ajarannya dianggap bertentangan dengan ajaran agama. Sebagai akibat dari kebijakan inilah maka beberapa ahli pikir yang merasa terbelenggu kebebasannya dalam mengekspresikan pemikiranpemikirannya melakukan eksodus ke Persia. Sebaliknya, Maha raja Persia dengan sukarela menerimanyauntuk tinggal di dalam daerah kekuasaannya, sehingga wajar apabila tidak lama berselang kemudian berdirilahpusat-pusat studifilsafat di daerah yang baru tersebut. Salah satu diantaranya di kota Jundishapur yang letaknya tidak jauh dari Baghdad yang didirikan pada tahun $762 \mathrm{M}^{2}$

Di saat Islam lahir, segera setelah itu agama ini menguasai daerah tersebut. Dengan dikuasainya daerah tersebut di bawah kekuasaan Islam, terlebih pada masakekuasaan Islam di bawah Bani Abbas (al-Ma'mun dan sesudahnya) muncullah pemikiran-pemikiran baru sebagai akibat dari adanya pergumulan dan interaksi antara kedua budaya tersebut. ${ }^{3}$ Sebagai akibat dari adanya pengaruh kegiatan ini -terutama penterjemahan- maka muncullah dalam 
SAFII: Ibn Miskawaih: Filsafat al-Nafs dan al-Akhlāq

sejarah beberapa ilmuwan dan filosof Islam yang cukup fenomenal dan populer. Ia dikenal bukan hanya di dunia Muslim, tetapi juga di dunia Barat dan salahsatunyaadalahIbn Miskawaih.

Ibn Miskawaih dikenal tidak hanya dalam bidang filsafatnya melainkan juga dalam bidang disiplin keilmuan lainnya, seperti sejarah dan sastra Arab. Bahkan melalui salah satu master piece-nya yang berjudul Tahżīb al-Akhlāq wa Tatkhīr al-A'rāq namanya menjadi semakin populer di berbagai belahan dunia. Oleh karena itu, dalam kesempatan ini penulis memandang perlu untuk menampilkan sosok Ibn Miskawaih tersebut dengan stressing kajian pada telaah pemikirannya tentang filsafat al-nafs dan al-akhlak-nya.

\section{B. Ibn Miskawaih: Sekilas tentang Biografi dan Karya- karyanya}

Nama lengkapnya adalah Abu Ali Ahmad ibn Muhammad ibn Ya'kub ibn Miskawaih.. Ia dilahirkan di kota Ray sekitar tahun 330 H. Kakeknya dikenal sebagaipenganut agama Majusi yang kemudian masuk Islam.

Pelajaran yang pernah digelutinya antara lainsejarah yang dipelajarinyadari Abu Bakr Ahmad ibn Kamil al-Qadi. Sementara filsafat dipelajarinya dari Ibn al-Kamal dan ilmu kimia dipelajarinya dari al-Razi. Di samping itu ia juga menghabiskan sebagian waktunya guna mendalami bahasa dan sastra Arab. ${ }^{6}$

Sepanjang hidupnya Ibn Miskawaih dikenal sebagai orang yang sangat committed dengan konsep yang ditulisnya tentang akhlak. Artinya antara teori yang dikedepankannya dengan tindakan praktisnya selalu sejalan. Bahkan melalui salah satu karyanya yang berjudul Tahżīb al-Akhlāq yang kemudian menjadimaster piece-nya, namanyakian menjadi harum.

Dalam melontarkan gagasan-gagasannya, Ibn Miskawaih dikenal sebagai salah seorang sinkretis. ${ }^{7}$ Gagasan-gagasannya dilontarkannya setelah ia meng amati situasi dan kondisisosial yang 
SAFII:Ibn Miskawaih: Filsafat al-Nafs dan al-Akhlāq

berkembang pada masa itu sangat kacau, di mana minum-minuman dan anak-anak yang lahir di luar nikah demikian merajalela di tengah-tengah masyarakat. Bahkan ia telah ikut larut menghabiskan sebagian waktu mudanya dalam memperturutkan keinginan nafsu birahinya dengan pelbagai perbuatan keji. ${ }^{8}$

Namun demikian, ia dalam perkembangannya diidentifikasi sebagai penganut Syi'ah yang devotif. Hal ini terbukti dengan pengabdiannya terhadap wazir-wazir dan raja-raja Syi'ah, serta banyak memuji orang-orang Syi'ah baik dalam tulisan-tulisannya maupun dalam pembicaraannya. ${ }^{9}$

Dalam perjalanan karirnya ia pernah pula menjadi bendaharawan Sultan Adhdu-Daulah dari Bani Buwaih. Akhirnya pada tanggal 16 Pebruari $1030 \mathrm{M} / 421 \mathrm{H}$, ia menemuiajalnya dengan meninggalkan beberapatulisan yang kesemuanya berjumlah 30 judul buku. ${ }^{10}$ Diantaranya karya-karyanya adalah: 1) al-Fauz al-Akbar, 2) al-Fauz al-Aṣghar 3) Tahżīb al-Akhlāq wa Tatkhir al-A'raq, ketiganya menguraikan masalah etika. 4) Risālah fi al-Lazzāt wa al-'Alam fi Zauhār al-Nafs, risalah tentang perasaan yang menyenangkan dan menyakitkan baik lahir maupun batin, 5) Tajārib alUmām,uraiantentang sejarah. 6) Tartīb al-Sa'ādah, mengenai etika dan politik terutama mengenai khilafah Bani 'Abbas dan Bani Buwaih, 7) Țahārah al-Nafs, uraiantentang kesucian jiwa, 8) Maqālah fi al-Nafswa al-'Aql, pandangantentangjiwa dan akal.

\section{Falsafat al-Nafs}

Masalah al-nafs (jiwa) telah menjadi bahan perbincangan yang secara perenial berkepanjangan.Demikian pula dengan Ibn Miskawaih, ia dikenal sebagai seorang pemikir yang sangat mementingkan pengetahuan tentang jiwa. Karena dari sinilah ia kemudian membangun teori akhlaknya.

Sebagaimana filosof-filosof Islam lainnya dalam membahas tentang jiwa ia pun terpengaruh juga dengan pemikiran-pemikiran 
filosof Yunani. ${ }^{11}$ Ia berpendapat bahwa dalam diri manusia terdapat dua unsur yaitu unsur tubuh (jasad) dan unsur jiwa (al-nafs). Antara keduanya terdapat esensi dansubstansi yang berbeda-beda, jadi tegasnya jiwa bukan tubuh bukan pula bagian dari tubuh dan bukan pula materi (al-'arḍ), akan tetapi suatu jauhar yang tunggal yang tidak dapat diraba dengan panca indera manapun tetapi dirasakan adanya, mengetahui, aktif dan bukan materi. ${ }^{12}$

Akan tetapi bagaimanakah untuk membuktikan antara keduanya? Dalam hal ini ia mengatakan bahwa setiap materi menerima forma (bentuk) tertentu. ${ }^{13}$ Artinya apabila ia telah menerima forma tertentu dalam satu waktu maka ia tidak bisa lagi menerima forma yang lain kecuali setelah ia berpisah dengan formanya yang pertama di atas. Sebagai contoh ungkap Ibn Miskawaih, apabila suatu materi sedang menerima forma segitiga, ketika itu ia tidak akan dapat menerima forma segi empat, lingkaran dan lain-lain kecuali sesudah ia berpisah dariformanya yang pertama tadi.

Berbeda dengan jiwa yang bisa menerima segala forma dari sesuatu, baik yang konkrit maupun yang abstrak secara sempurna, bentuk pertama yang diterima oleh jiwa tidak akan lenyap oleh datangnya bentuk kedua dan seterusnya. ${ }^{14}$ Oleh sebab itulah maka pengetahuan manusia itu selalu bertambah. Artinya sewaktu ia menerima pengetahuan yang baru maka pengetahuan yang lama tidak akan lenyap.

Dengan demikian jelaslah bahwa jiwa itu menurutnya mempunyai substansi dan esensi tersendiri yang terlepas dari badan.Bahkan lebih dari itu kedudukan jiwa itu sendiri dalam pandangannya lebih mulia dari badan itu sendiri.Hal ini menurutnya terbukti dari kemauan jiwa yang memiliki kecenderungan pada sesuatu yang bukan jasadi atau ingin mengetahui realitas ketuhanan, atau ingin dan lebih menyukai apa-apa yang lebih mulia daripada hal-hal jasmani, serta menjauhkan diri dari kenikmatan jasmani 
SAFII:Ibn Miskawaih: Filsafat al-Nafs dan al-Akhlāq

demi mendapatkan kenikmatan akal. Sebagai konsekuensinya maka jiwa itu menurutnya adalah kekal, ia tidak akan hancur dengan hancurnya jasad. Dan jiwa itulah nantinya yang akan menerima pembalasan di akhirat. Jadijiwalah yang akanbahagiaatausengsara di akhirat nanti. Kebahagiaan jasmani bersifat temporal tetapi kebahagiaan rohani yang dirasakan jiwa adalah abadi. ${ }^{15}$

Kemudian dalam kaitannya dengan akal, Ibn Miskawaih menerangkan bahwa antara jiwa dan akal itu satu adanya. ${ }^{16}$ Artinya jiwa dan akal dalam pandangannya tidaklah dibedakan.Bahkan akal baginya justru merupakan salah satu daya dari daya-daya yang ada dalam jiwa dan merupakan manifestasi dari adanya jiwa itu sendiri. ${ }^{17}$ Dengan demikian dapatlah dikatakan bahwa akal baginya merupakan salah satu bukti bagi adanya jiwa.

Telaah Ibn Miskawaih tentang jiwa dan badan tersebut membawanya pada pembahasan yang lebih dalam tentang jiwa itu sendiri. Menurut pendapatnya bahwa jiwa yang ada dalam diri manusia itu sebagaimana keterangan Yunasril Ali, memiliki tiga kekuatan (fakultas), yaitu: pertama kekuatan untuk berpikir memahami dan membedakan sesuatu; kedua kekuatan untuk marah berlaku berani, rindu kepada kekuasaan dan sebagainya; ketiga kekuatan yang menimbulkan syahwat, makan, minum dan kelezatan-kelezatan fisik lainnya. ${ }^{18}$

Dari ketiga kekuatan tersebut masing-masing kemudian oleh Ibn Miskawaih diistilahkan dengan fakultas raja untuk menyebut fakultas berpikir (al-quwwah al-nātīqah) dan organ tubuh yang dipergunakannya adalah otak, fakultasbinatang untuk menyebut fakultas nafsu syahwiyah dan organ tubuh yang dipergunakannya adalah hati, dan fakultas binatang buas untuk menyebut fakultas amarah (al-Quwah al-Ghadabiyah) dan organ tubuh yang dipergunakannya disebut jantung. ${ }^{19}$ 
SAFII: Ibn Miskawaih: Filsafat al-Nafs dan al-Akhlāq

\section{Falsafah al-Akhlāq}

Sebagaimana pembahasannya tentang jiwa, dalam masalah akhlak Ibnu Miskawaih seperti disinyalir oleh Ahmad Mahmud Subhi juga banyak meramu dari pendapat-pendapatAristoteles, Plato, Jalinus dan Birsan utamanya dari syariat Islam. ${ }^{20}$

Secara etimologi kata akhlak berasal dari bahasa Arab. Ia merupakan bentuk jamak dari kata khuluq yang berarti tabiat atau budi pekerti. ${ }^{21}$ Istilah ini menurut Sudarsono memiliki segi-segi kesesuaian dengan istilah khuluqun sebagai masdar yang berkaitan dengan fā'il yakni khāliqun, juga berhubungan dengan mafūl ialah makhlūqun. Ditinjau dari segi rangkaian pemakaian istilahnya, tampak sekali bahwa akhlak mempunyai dua segi kehidupan manusia yakni segi vertikal dan segi horizontal. ${ }^{22}$

Adapun secara terminologi Ibn Miskawaih sebagai yang dikutip Ahmad Daudy, mendefinisikan akhlak sebagai suatu sikap mental (hâlun li al-nafs) yang mendorongnya untuk berbuat tanpa pikir dan pertimbangan. ${ }^{23}$ Sikap mental tersebut terbagi menjadi dua, yaitu yang berasal dari naluri (watak) dan yang berasal dari kebiasaan dan latihan. Akhlak yang berasal dari naluri menurutnya dapat diubah dan diarahkan dengan jalan pelatihan dan pembiasaan. ${ }^{24}$ Karena kalau tidak menurutnya tentunya agama tidak akan ada artinya diturunkan kepada umat manusia. Padahal jelas bahwa tujuan pokokdari agama sebagai keterangan Ahmad Daudy adalah untuk mengajarkan sejumlah nilai-nilai akhlak mulia agar mereka menjadi baik dan bahagia dengan melatih diri menghayatinya. ${ }^{25}$ Dengan demikian dapatlah dikatakan bahwa antara agama dan akhlak terdapat keharmonisan dimana keduanya berfungsi untuk memperbaiki tingkah laku perbuatan manusia.

Kemudian tentang masalah baik dan buruk Ibn Miskawaih berpendapat bahwa kebaikan merupakan hal yang dapat dicapai oleh manusia dengan melaksanakan kemauannya dan dengan berupaya dan dengan hal-hal yang berkaitan dengan tujuan manusia. 
SAFII:Ibn Miskawaih: Filsafat al-Nafs dan al-Akhlāq

Bahkan lebih dari itu ia sebagaimana dikutip MM. Syarif berpendapatbahwaapa yang berguna bagi pencapaian tujuan tersebut adalah baik, misalnya sarana-sarana dan tujuan itu sendiri dapat disebut baik. ${ }^{26}$ Sebaliknya keburukan adalah hal yang menjadi penghambat manusia dalam mencapai kebaikan, baik hambatan berupa kemauan dan upayanya maupun berupa kemalasan dan keengganannya mencari kebaikan. Kebaikan itu sendiri lanjutnya hanya berada dalam objek, namun kebaikan yang ada dalam objek itu dipandang oleh manusia dengan kacamata yang berbeda-beda. Artinya karena perbedaan alat dan cara pandang manusia terhadap kebaikan itu sendiri, kebaikan itu menjadi beragam.

Dari berbagai pendapat itu ada yang mengatakan bahwa kebaikan itu terbagi menjadi tiga macam, yaitu: sesuatu yang mulia, sesuatu yang terpuji dan sesuatu yang bermanfaat. ${ }^{27}$ Ada lagi yang berpendapat bahwa kebaikan itu terdiri dari dua, yaitu: kebaikan yang sempurna dan kebaikan yang tidak sempurna. ${ }^{28}$

Berkenaan dengan kebaikan tersebut ia sebagaimana dikutip Ahmad Daudy menolak pendapat orang yang mengatakan adanya sifat-sifat keutamaan (kebaikan-pen) dalam hidup zuhud, menyendiri dari kehidupan sosial dengan bertempat tinggal di gua-gua, gunung-gunung ataupun pergi mengembara di seluruh nusantara. ${ }^{29}$ Karena lanjutnya kebaikan itu tidak bersifat anti sesuatu atau bersifat negatif, tetapi bersifat tindakan atau perbuatan positif yang lahir dari keikutsertaan orang dalam hidup sosial. ${ }^{30}$

Kemudian tentang masalah kebahagiaan ${ }^{31}$ yang merupakan bagian dari kebaikan itu sendiri menurutnya bisa dirasakan manusia baik oleh jasadnya maupun oleh jiwanya.Pendapat ini boleh dikatakan merupakan hasil kompromi dari pandangan para pemikir Yunani sebelumnya terutama yang diwakili oleh Plato dan Aristoteles. ${ }^{32}$ Karena kebahagiaan itu bisa dirasakan manusia melalui kedua unsur tersebut maka kebahagiaan itu menurutnya ada dua tingkat, yaitu: orang yang sangat terikat dengan hal yang material 
dan mendapatkan kebahagiaan dengannya, tetapi bersamaan dengan itu ia rindu pada hal-hal yang spiritual serta berusaha memperolehnya dengan segala upaya dan orang yang sangat terikat dengan hal-hal yang spiritual/rohani, dan memperoleh kebahagiaan dengannya, tetapi bersamaan dengan itu ia rindu kepada hal-hal yang material dengan memandangnya sebagai tanda-tanda kekuasaan Allah dan dalil-dalil kebijaksanaannya. ${ }^{33}$ Kebahagiaan pada tingkat pertama menurutnya selalu disertai kepayahan dan kepedihan tetapi kebahagiaan pada tingkat kedua lebih sempurna dan lebih kekal nikmatnya. ${ }^{34}$ Dan kebahagiaan itu katanya hanya bisa diperoleh apabila ia telah memutus hubungan dengan hal-hal yang material, sehingga ia tidak lagi mengalami apa yang dikatakan sebagai kepedihan dan penyesalan. ${ }^{35}$ Apabila ia berhasil melepaskan dirinya dari ikatan tersebut, maka menurutnya ia akan naik ke tingkat derajat kesempurnaan, yang menurut istilahnya sendiri disebut tingkat malaikat, makhluk Allah yang paling sempurna. ${ }^{36}$

\section{E. Penutup}

Sebagai seorang religius sejati Ibn Miskawaih meyakini bahwa manusia itu pada dasarnya diciptakan Tuhan dalam dua unsur yaitu unsur jasad dan jiwa jasad manusia akan hancur dengan lepasnya jiwa sebaliknya jiwa akan tetap hidup dengan hancurnya jasad. Diantara kedua unsur tersebut dalam pandangannya sama-sama dapat memperoleh kebahagiaan hanya saja kebahagiaan yang dialami jasad bersifat temporal sebaliknya kebahagiaan yang dialami jiwa lebih esensial dan lebih kekal.

Manusia dikatakan baik akhlaknya apabila mau berusaha mencurahkan segenap perhatiannya pada upaya mewujudkan tujuan diciptakannya manusia itu sendiri, sebaliknya akhlak manusia dikatakan buruk apabila ia tidak bisa menghindarkan dirinya dari 
SAFII:Ibn Miskawaih: Filsafat al-Nafs dan al-Akhlāq

kendala yang merintangi terhadap pencapaian tujuan diciptakannya manusia tersebut.

Sebagai seorang pemikir religius sejati, ia boleh dikata bahwa dalam menuangkan gagasan-gagasannya tidak melulu bersifat teoritis melainkan lebih menekankan pada tindakan praktis. Hal ini telah dibuktikan olehnya dalam menyikapi kehidupan realitas sehari-hari.]

\section{Catatan Akhir}

${ }^{1}$ Hellenisme adalah suatu kebudayaan campuran antara kebudayaan Yunani dengan kebudayaan lain yang terdapat di kawasan tersebut. Lihat Ahmad Daudy, Kuliah Filsafat Islam, Jakarta: Bulan Bintang, 1986, h. 1.

2LihatHarunNasution, Falsafah dan Mistisisme dalam Islam, Jakarta: Bulan Bintang, 1973, h. 11.

${ }^{3}$ Lihat Ibrahim Madkur, Filsafat Islam Metode dan Penerapan,terj. Yudian Wahyudi dan Ahmad Hakim al-Mudzakir, Jil.I, Jakarta: Rajawali, 1991, h. 12.

4la disebut juga dengan Abū Ali al-Khāzin. LihatYunasril Ali, Perkembangan PemikiranFilsafat dalam Islam, Jakarta: Bumi Aksara, 1991), h. 53

5Muhammad Yusuf Musa, Falsafah al-Akhlak fi al-Islām, alQahirah: Muassasah al-Khariji, 1963, h. 74.

6Yunasril Ali, Perkembangan Pemikiran, h. 53-54.

${ }^{7}$ Artinya seorang yang mencampurbaurkan kebudayaan Yunani dengan kebudayaan Islam, filsafat Romawi dan Hindu dengan filsafat Arab. Lihat Proyek Pembinaan PerguruanTinggi Agama (PPPTA), PengantarFilsafat Islam, Banda Aceh: IAIN Jami'ahArraniri, 1983, h. 57.

${ }^{8}$ Ahmad Daudy, KuliahFilsafat, h. 58.

${ }^{9}$ PPPTA, Pengantar Filsafat Islam, h. 58.

${ }^{10} \mathrm{MM}$. Syarif, History of Moslem Philosophy, jilid I, Otto Horra Sowitz: Weisbaden, 1963, h. 469.

${ }^{11}$ Seperti Plato, Aristoteles dan Jelinus. Lihat PPPTA, PengantarFilsafat, h. 60. 
12Ahmad Amin, Zahr al-Islām, Juz II, Kairo: t.p., 1962, h. 181.

13Dalam hal ini tampak sekali pengaruh dari pemikiran Aristoteles tentang forma dan materi.

${ }^{14}$ Y unasril Ali, Perkembangan Pemikiran, h. 56.

15Ibid., h. 58, juga Ahmad Daudy, KuliahFilsafat, h. 59

${ }^{1}$ Y unasril Ali,Perkembangan Pemikiran, h. 57

${ }^{17}$ Ibid.

18Ibid.

19Ibid., h. 44

${ }^{20}$ Aḥmad Maḥmūd Șubḥī, al-Falsafat al-Akhlāqiyah fi al-Fikri alIslām, Mesir: Dār al-Ma'ārif, 1119 H, h. 312; Ahmad Amin,Etika/Ilmu Akhlak, terj. Farid Ma'ruf, Jakarta: Bulan Bintang, 1986, h. 149

${ }^{21}$ Ahmad Warson Munawir, al-Munawir Kamus Arab Indonesia, Yogyakarta: al-Munawir, 1984, h. 393.

${ }^{22}$ Sudarsono, Etika Islam tentang Kenakalan Remaja, Jakarta: Bina Aksara, 1989, h. 125.

${ }^{23}$ Ahmad Daudy, KuliahFilsafat, h. 61. Juga dalam Sudarsono, Etika Islam, h. 129.

${ }^{24} \mathrm{Hal}$ itu ditegaskannya sebagai respon terhadap pandangan sebagian pemikir Yunani yang berpendapat sebaliknya. Lihat Ahmad Daudy, Kuliah Filsafat, h. 61.

25Ibid.

26M.M. Syarif, Para Filosof Muslim, terj. Ilyas Hasan, Bandung: Mizan, 1992, h. 92

27Yunasril Ali, PerkembanganPemikiran, h. 55

${ }^{28}$ Kebaikan yang sempurna dicontohkan seperti bahagia yang merupakan tujuan dan tumpuan niat. Sedangkan kebaikan yang tidak sempurna seperti sehat, ia merupakan media untuk menuju kebahagiaan yang hakiki. Yunasril Ali, PerkembanganPemikiran, h. 5556.

${ }^{29}$ Ahmad Daudy, KuliahFilsafat, h. 63-64.

30Ibid., h. 64

${ }^{31}$ Kebahagiaan di sini menurutnya merupakan kesempurnaan dan akhir dari kebaikan. 
32Plato berpendapat bahwa kebahagiaan dialami oleh jiwanya semata, bukan oleh jasmaniah.Sementara Aristoteles mengatakan manusia dapat memperoleh kebahagiaan dalam kehidupan dunia ini, yakni dalam hal jiwa masih terikat dengan badan. Lihat Ahmad Daudy, Kuliah Filsafat, h. 64. Juga MM. Syarif, Para Filosof, , h. 93

${ }^{33}$ Ahmad Daudy, Kuliah Filsafat, h. 65

${ }^{34}$ Lihat, Yunasril Ali, Perkembangan Pemikiran, h. 56

${ }^{35}$ Ahmad Daudy, Kuliah Filsafat, h. 65

36Ibid. 


\section{DAFTARPUSTAKA}

Amin, Ahmad, Etika/Ilmu Akhlak,terj. Farid Ma'ruf, Jakarta: Bulan Bintang, 1986.

Daudy, Ahmad, KuliahFilsafat Islam, Jakarta: Bulan Bintang, 1986.

Madkur, Ibrahim, Filsafat Islam Metode dan Penerapan, terj. Yudian Wahyudi dan Ahmad Hakim al-Mudzakir,Jil. I, Jakarta: Rajawali, 1991.

Munawir, Ahmad Warson, al-Munawir Kamus Arab Indonesia, Yogyakarta: al-Munawir, 1984.

Mūsā, Muhạmmad Yūsuf, Falsafah al-Akhlāq fí al-Islām,Kairo: Muassasah al-Khariji, 1963.

Nasution, Harun, FalsafatdanMistisismedalam Islam, Jakarta: Bulan Bintang, 1973.

Proyek Pembinaan Perguruan Tinggi Agama (PPPTA), Pengantar Filsafat Islam, Banda Aceh: IAIN Jami'ah Arraniri, 1983.

Ṣubḥ̄, Aḥmad Maḥmūd al-Falsafat al-Akhlāqiyah fi al-Fikri alIslām,Mesir: Dār al-Ma'ārif, 1119 H.

Sudarsono, Etika Islam tentang Kenakalan Remaja, Jakarta: Bina Aksara, 1989.

Syarif, M.M., Para Fillosof Muslim,terj. Ilyas Hasan, Bandung: Mizan, 1992.

Yunasril Ali, PerkembanganPemikiran Filsafat dalam Islam, Jakarta: Bumi Aksara, 1991. 